\title{
HAEMAGGLUTINATION ACTIVITY OF THE EXTRACTS FROM SOME VIETNAM MARINE INVERTEBRATES
}

\author{
Dinh Thanh Trung', Vo Thi Dieu Trang', Ngo Thi Duy Ngoc ${ }^{1}$, Phan Thi Hoai Trinh ${ }^{1}$, Tran Thi Hai \\ Yen $^{2}$, Le Dinh Hung 1 , \\ ${ }^{1}$ Nha Trang Institute of Technology Research and Application, Vietnam Academy of Science and Technology \\ ${ }^{2}$ Le Quy Don Highschool for the Gifted, Khanh Hoa
}

${ }^{凶}$ To whom correspondence should be addressed. E-mail: ledinhhungims@yahoo.co.uk

Received: 16.11 .2016

Accepted: 29.7.2017

\section{SUMMARY}

\begin{abstract}
Aqueous extracts from 21 species of Vietnam marine invertebrates, including 11 bivalve and 10 gastropod species, were examined for haemagglutination activity using native and enzyme-treated different animal and human erythrocytes. The 8 bivalve and 10 gastropod species were found to have haemagglutinination activities toward at least one type of erythrocyte tested. A total of $86 \%$ of marine invertebrate species surveyed were active. Strong activity was detected in extracts from two bivalve species (Tridacna squamosa and Geloina coaxans) and three gastropod species (Tutufa rubeta, Pleuroploca trapezium and Tectus conus) with enzymetreated rabbit, horse and human A, B, O erythrocytes. In a haemagglutination-inhibition test with various monosaccharides and glycoproteins, haemagglutination activities of two extracts from T. rubeta and $P$. trapezium had no affinity for any of the monosaccharides and glycoproteins tested, while activities of the extracts from $T$. squamosa and $T$. conus were strongly inhibited by porcine stomach mucin tested, suggesting the presence of lectins specific for O-glycans of these species. The activities of four marine invertebrate extracts were stable over a wide range ofpH and temperature. The haemagglutination activities of $T$. rubeta and $P$. trapezium extracts were independent of the presence of divalent cations, whereas the haemagglutination activity of extracts from $T$. squamosa and $T$. conus were slightly dependent on the presence of divalent cations. The results suggest that Vietnam marine invertebrates may be good sources of useful lectins for biochemical and biomedical applications.
\end{abstract}

Keywords: Carbohydrate-binding specificity; Haemagglutination activity; Lectins; Marine invertebrates; Stability; Survey

\section{INTRODUCTION}

Marine bioresources such as marine cyanobacteria, algae, invertebrate animals, and fishes produce a great variety of specific and potent bioactive molecules, such as fatty acids, polysaccharides, polyether, peptides, proteins, and enzymes. To date, many researchers focused on the marine natural products and their various pharmacological functions to develop new potent drugs including antimicrobials, anti-human immunodeficiency virus (HIV), anticancer, and Alzheimer's therapeutics (Vo, Kim, 2010). In the drug discovery from natural resources, lectins are one of the promising candidates for useful therapeutic agents because they can recognize carbohydrate structures such as proteoglycans, glycoproteins and glycolipids, and have been implicated in certain cell types and their physiological and pathological functions including host-pathogen interactions and cell-cell communications (Lakhtin et al., 2011). Although in most cases physiological functions of invertebrate lectins are not completely clear, there are increasing data suggesting the involvement of these lectins in processes of differentiation and development of organisms as well as in elimination of foreign substances through binding to their carbohydrate structures (Kawsabata, Tsuda, 2002; ArreguinEspinosa et al., 2001). Marine invertebrates survive in environments rich in bacterial populations, many of which may be pathogenic (Austin, 1988). The immune defense of these animals is non-specific with responses against microbial organisms based on 
both cellular and humoral activities (Chu, 1988; Canesi et al., 2002). In marine animals, humoral lectins have been shown to participate actively the same as opsonins (Bayne, 1990). Lectins are ubiquitous proteins in the hemolymph and cells of many invertebrates (Renwrantz, 1986; Cooper et al., 1992) with the activity based in the carbohydratebinding protein that produces the agglutination of many cells, such as erythrocytes, bacteria, and others through interaction with specific complementary ligands (Nesser et al., 1986). Interestingly, it has been theorized that some marine invertebrate lectins mediate the interaction between symbiont and host (Vasta, 1992). They represent a heterogeneous group of oligomeric proteins that vary widely in size, structure, molecular organization, and constitution of their combining sites. In recent years, there have been several surveys on distribution of haemagglutinins in marine invertebrates from Brazil (Moura et al., 2015) and the Philippines (Mojica et $a l ., 2005)$ and the variety of lectins have been purified and characterized from marine invertebrates (Moura et al., 2006; Xiong et al., 2006; Molchanova et al., 2007; Kawsar et al., 2009). Characterization studies reveal that animal lectins are classified into several categories: C-type lectins (CTLs), galectins, I-type lectins, pentraxins, P-type lectins, tachylectins, and so forth (Gabius, 1997). Among lectins isolated from marine invertebrates, lectins from the marine worms Chaetopterus variopedatus and Serpula vermicularis inhibited cytopathic effect induced by HIV-1 and could block the cell-to-cell fusion process of HIV infected and uninfected cells (Wang et al., 2006); lectins from mussel Crenomytilus grayanus and acidium Didemnum ternatanum inhibited the HIV-1 IIIB-induced syncytium formation in C8166 cells and had activity against cellular fusion between the H9/HIV-1 chronically infected cells and the C8166 uninfected cells (Luk'yanov et al., 2007). Thus, marine invertebrate lectins may promise as a potential candidate for the development of novel antiviral agents.

Vietnam is located in the tropical and subtropical zone with a long coast line of about $3,260 \mathrm{~km}$ where there is a rich marine biodiversity of algae, invertebrates, bacteria, viruses, etc. Such species may be potential sources for studies and application of lectins. However, only little information is known about lectins from Vietnam marine organisms, including several reports on lectins from marine invertebrates (Cao Dang Nguyen, 1998), (Cao Dang Nguyen, Nguyen Quoc Khang,
1998), (Cao Dang Nguyen et al., 2000, 2008), (Nguyen Quoc Khang et al., 2000) and from marine algae (Le Dinh Hung et al., 2009a, 2009b, 2011, 2012, 2015a, 2015b). Thus, the objective of this research was to survey haemagglutinins from Vietnam marine invertebrates, which will provide more valuable information for future applications.

\section{MATERIALS AND METHODS}

\section{Materials}

Twenty one specimens of marine invertebrates including 11 bivalve and 10 gastropod species were collected at Khanh Hoa province of Vietnam from July, 2015 to May, 2016. After collection, they were immediately transferred to the laboratory on ice and kept at $-20^{\circ} \mathrm{C}$ until used. The marine invertebrate samples were collected and identified by MSc. Bui Quang Nghi - Institute of Oceanography, Vietnam. Blood from rabbit, sheep and horse was obtained from the Institute of Vaccine - Nha Trang, Vietnam, and human $\mathrm{A}, \mathrm{B}$, and $\mathrm{O}$ blood were obtained from Khanh Hoa General Hospital, Vietnam. Transferrin, fetuin, porcine thyroglobulin, porcine stomach mucin (Type III), D-glucose, D-mannose, D-galactose, Nacetyl-D-glucosamine, N-acetyl-D-mannosamine, Nacetyl-D-galactosamine and Tris (hydroxymethyl)aminomethane (Tris) were purchased from Sigma Chemical Co. Yeast mannan and $\mathrm{N}$-acetylneuraminic acid were obtained from Nakarai Chemical Co.

\section{Preparations of invertebrate extracts and ammonium sulfate-precipitates}

A $20 \mathrm{~g}$ sample of each invertebrate was cut into small pieces, homogenized for $1 \mathrm{~min}$ in a blender with 2 volumes of Tris- $\mathrm{HCl}$ buffer $20 \mathrm{mM}$, pH 7.5 containing $\mathrm{NaCl} 150 \mathrm{mM}$ (TBS), and kept at $4^{\circ} \mathrm{C}$ for $12 \mathrm{~h}$ with occasionally stirring. After filtration through a cheese cloth, the filtrate was centrifuged at $10,000 \mathrm{rpm}$ for $30 \mathrm{~min}$. The supernatants were recovered and stored at $-20^{\circ} \mathrm{C}$ until used. Haemagglutination tests were carried out with erythrocytes of various human and animals in a native state or enzyme-treated with trypsin and papain. To the supernatant (extract), solid ammonium sulfate was slowly added to attain $75 \%$ saturation. The mixture was gently stirred and then kept at $4^{\circ} \mathrm{C}$ for $18 \mathrm{~h}$. Precipitates were recovered by centrifugation at 10,000 rpm for $20 \mathrm{~min}$, dissolved in a small volume of TBS, and thoroughly dialyzed against the same buffer. The non-dialyzable fraction 
was recovered as an ammonium sulfate-precipitate (Kawsar et al., 2009). The ammonium sulfateprecipitates obtained were used for both haemagglutination-inhibition and stability tests.

\section{Preparation of a $2 \%$ suspension of native or enzyme-treated erythrocytes}

Each blood sample was washed three to five times with 50 volumes of saline. After washing, a $2 \%$ erythrocyte suspension $(\mathrm{v} / \mathrm{v})$ was prepared in saline and used as native erythrocytes. Trypsin- or papain-treated erythrocytes were prepared as follows. One-tenth volume of $0.5 \%$ $(\mathrm{w} / \mathrm{v})$ trypsin or papain solution was added to a $2 \%$ native erythrocyte suspension, and the mixture was incubated at $37^{\circ} \mathrm{C}$ for $60 \mathrm{~min}$. After incubation, the erythrocytes were washed three to five times with saline and a $2 \%$ suspension ( $/ \mathrm{v})$ of trypsin- or papain-treated erythrocytes was prepared in saline.

\section{Haemagglutination assay}

Haemagglutination assays were carried out using a microtiter method in a 96-well microtiter V-plate (Le Dinh Hung et al., 2009a). First, $25 \mu \mathrm{L}$ of serially two-fold dilutions of a test solution were prepared in saline on a microtiter V-plate. To each well, $25 \mu \mathrm{L}$ of a $2 \%$ erythrocyte suspension was added and the mixtures gently shaken and incubated at room temperature for $2 \mathrm{~h}$. A positive result was indicated by formation of a uniform layer of coagulant over the surface of the well. On the other hand, a negative test result was indicated by the formation of a discrete "button" at the bottom of the well. Haemagglutination activity was expressed as a titer, the reciprocal of the highest two-fold dilution exhibiting positive haemagglutination. The assay was carried out in duplicate foreach test solution.

\section{Haemagglutination-inhibition test}

Of the six erythrocytes used, human $\mathrm{O}$ erythrocytes were selected for haemagglutinationinhibition tests, using ammonium sulfate-precipitates according to the method previously described (Kawsar et al., 2009). First, $25 \mu \mathrm{L}$ of serially twofold dilutions of sugar or glycoprotein were prepared in saline. To each well, an equal volume of extract solution with a haemagglutination titer of eight was added, and the plate was mixed gently and allowed to stand at room temperature for $1 \mathrm{~h}$. Finally, $25 \mu \mathrm{L}$ of a $2 \%$ suspension of trypsin-treated human $\mathrm{O}$ erythrocytes was added to each well, and the plate gently shaken and incubated for a further $1 \mathrm{~h}$. Inhibition was observed macroscopically and inhibition activity was expressed as the lowest concentration of sugar or glycoprotein at which complete inhibition of haemagglutination was achieved. The assay was performed in duplicate per sugar and glycoprotein. The following sugars and glycoproteins were tested: the monosaccharides: Dglucose, D-mannose, D-galactose, N-acetyl-Dglucosamine, $\mathrm{N}$-acetyl-D-mannosamine, $\mathrm{N}$-acetyl-Dgalactosamine, and $\mathrm{N}$-acetylneuraminic acid; and the glycoproteins: transferrin, asialo-transferrin, fetuin, asialo-fetuin, yeast mannan, porcine stomach mucin, asialo-porcine stomach mucin and thyroglobulin. Asialo-transferrin, asialo-fetuin and asialo-porcine stomach mucin were prepared by hydrolyses of their parent sialoglycoproteins with $0.05 \mathrm{M} \mathrm{HCl}$ for $1 \mathrm{~h}$ at $80^{\circ} \mathrm{C}$ followed by dialysis against saline overnight.

Effects on hemagglutination activity of divalent cations, $\mathrm{pH}$, and temperature

To examine the effects of divalent cations on hemagglutination activity, a $1 \mathrm{~mL}$ aliquot of an extract solution was dialyzed at $4^{\circ} \mathrm{C}$ overnight against $100 \mathrm{~mL}$ of $50 \mathrm{mM}$ EDTA in TBS. The nondialyzable fraction was recovered and haemagglutination activity in the presence or absence of divalent cations $\left(10 \mathrm{mM} \mathrm{CaCl}_{2}\right.$ or $\mathrm{MgCl}_{2}$ ) was determined. To examine the effect of temperature, a $1 \mathrm{~mL}$ aliquot of an extract solution was heated at various temperatures $\left(30-100^{\circ} \mathrm{C}\right)$ for $30 \mathrm{~min}$, then immediately cooled on ice, and haemagglutination activity was determined as above. To examine the effect of $\mathrm{pH}$, a $1 \mathrm{~mL}$ aliquot of an extract solution was dialyzed at $4^{\circ} \mathrm{C}$ overnight against $0.05 \mathrm{M}$ buffers of various $\mathrm{pH}$ from 3 to 10 and then dialyzed against saline to eliminate the $\mathrm{pH}$ effect. The non-dialyzable fractions were assayed for haemagglutination activity. The following buffers were used; acetate buffer for $\mathrm{pH}$ from 3 to 5, Tris$\mathrm{HCl}$ buffer for $\mathrm{pH}$ from 6 to 10 (Le Dinh Hung et al., 2009a). Haemagglutination activity was determined with trypsin-treated human $\mathrm{O}$ erythrocytes.

\section{RESULTS AND DISCUSSION}

The results of the screening for haemagglutination activity from extracts of some marine invertebrates are summarized in table 1 . The extract amount from marine invertebrate samples agglutinated the different types of erythrocytes expressed as \% (Figure 1). Sheep erythrocytes gave the most detection of the haemagglutination activity of crude extracts, followed by rabbit, horse and human A, B, O blood erythrocytes. 
Dinh Thanh Trung et al.

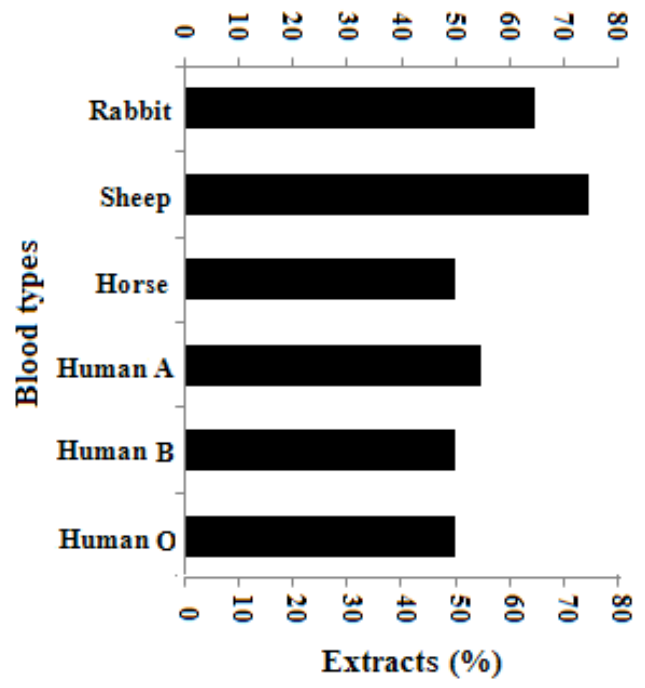

Figure 1. The extract amount agglutinated the different types of erythrocytes expressed as $\%$.

\section{Bivalves}

Of the 11 bivalve species surveyed, extracts from 8 species agglutinated at least one type of erythrocytes tested (Table 1). Extract from Tridacna squamosa showed strong activities with trypsin- or papain-treated human A, B and O erythrocytes, whereas it did not agglutinate sheep and horse erythrocytes, even when erythrocytes were treated by enzyme. The extract from Geloina coaxans agglutinated all types of erythrocytes tested and showed also strong activities with trypsin- or papain-treated horse erythrocytes following by human A, B and O erythrocytes. Extract from Atrina pectinata had relatively activities with enzyme- treated animal erythrocytes, but no haemagglutination was observed with the types of human erythrocytes irrespective of treatment with enzymes. In particular, the extracts from Crassostrea bilineata, Spondylus squamosus and Periglypta crispate did not agglutinate any type of human, rabbit, sheep and horse erythrocytes. Thus, the haemagglutination titers of the bivalve extracts were higher with animal erythrocytes than with human erythrocytes. These results were similar to those of screening for haemagglutination activity from Philippine marine invertebrates, which showed some haemagglutination activity against human red blood cell tested from bivalves (Mojica et al., 2005).

Table 1. Haemagglutination activity of extracts from some Vietnam marine invertebrates.

\begin{tabular}{|c|c|c|c|c|c|c|c|c|c|c|c|c|c|c|c|c|c|c|}
\hline \multirow[t]{3}{*}{ Species } & \multicolumn{18}{|c|}{ Haemagglutination titer of marine invertebrate extracts ${ }^{a}$} \\
\hline & \multicolumn{3}{|c|}{ Rabbit } & \multicolumn{3}{|c|}{ Sheep } & \multicolumn{3}{|c|}{ Horse } & \multicolumn{3}{|c|}{ Human A } & \multicolumn{3}{|c|}{ Human B } & \multicolumn{3}{|c|}{ Human 0} \\
\hline & $\overrightarrow{\mathbf{N}}$ & $\mathrm{T}^{\mathrm{c}}$ & $P^{d}$ & $\mathbf{N}$ & $\mathbf{T}$ & $\mathbf{P}$ & $\mathbf{N}$ & $\mathbf{T}$ & $\mathbf{P}$ & $\mathbf{N}$ & $\mathbf{T}$ & $\mathbf{P}$ & $\mathbf{N}$ & $\mathbf{T}$ & $\mathbf{P}$ & $\bar{N}$ & $\mathbf{T}$ & $P$ \\
\hline \multicolumn{19}{|l|}{ Mollusca } \\
\hline \multicolumn{19}{|l|}{ Bivalves } \\
\hline Arcidae & & & & & & & & & & & & & & & & & & \\
\hline $\begin{array}{l}\text { Anadara } \\
\text { antiquate } \\
\text { (Linnaeus, 1758) }\end{array}$ & - e & - & - & - & 4 & 2 & 2 & 2 & 2 & - & - & - & - & - & - & - & - & - \\
\hline $\begin{array}{l}\text { Tegillarca } \\
\text { nodifera } \\
\text { (Martens, 1860) }\end{array}$ & - & - & - & - & - & 8 & - & - & - & - & - & - & - & - & - & - & - & - \\
\hline Cardiidae & & & & & & & & & & & & & & & & & & \\
\hline
\end{tabular}


Journal of Biotechnology 15(4): 691-701, 2017

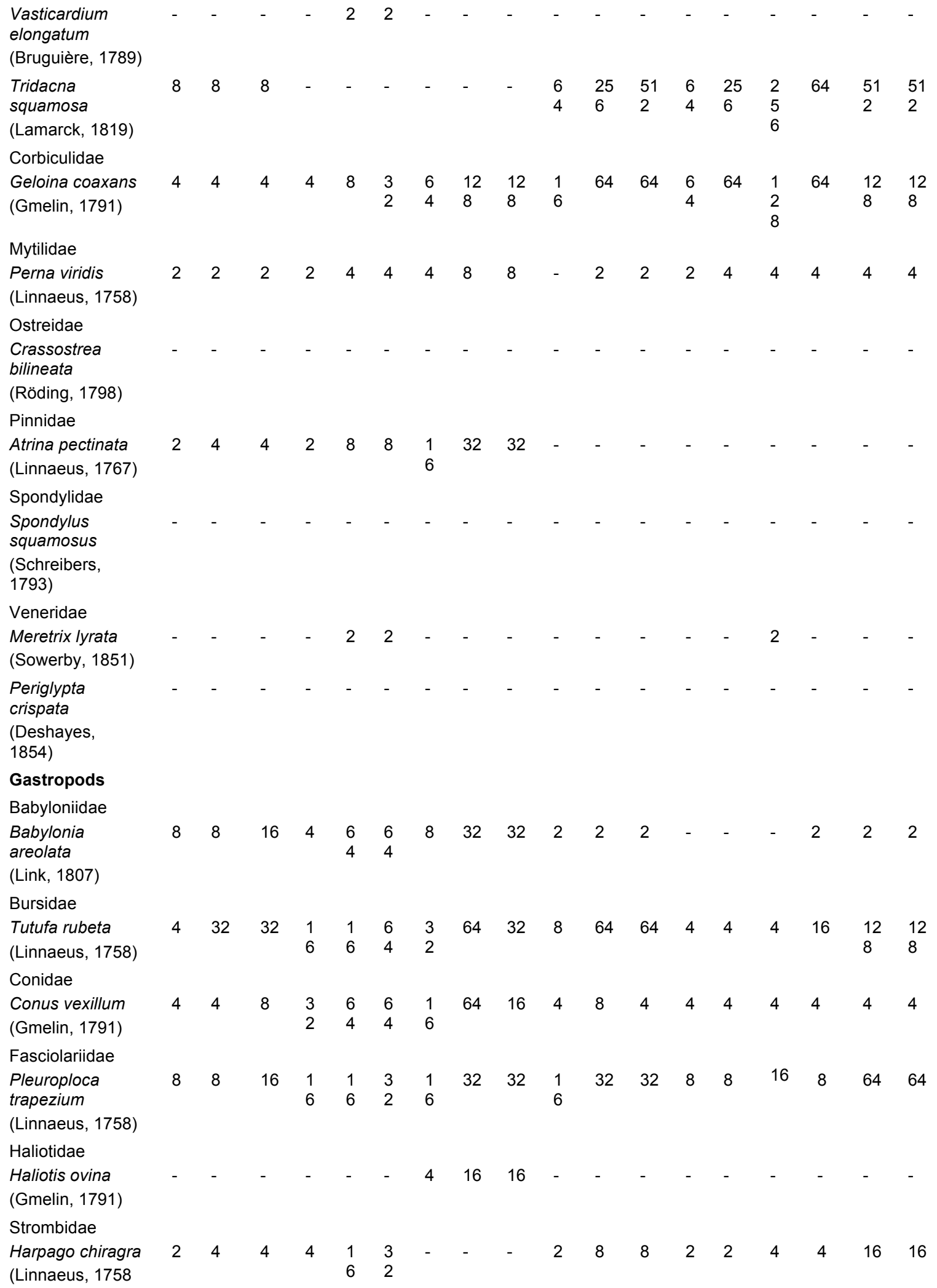




\begin{tabular}{|c|c|c|c|c|c|c|c|c|c|c|c|c|c|c|c|c|c|c|}
\hline $\begin{array}{l}\text { Lambis lambis } \\
\text { (Linnaeus, 1758) }\end{array}$ & 2 & 4 & 4 & - & 2 & 2 & - & - & - & - & - & - & & & & - & - & - \\
\hline Teligudae & & & & & & & & & & & & & & & & & & \\
\hline $\begin{array}{l}\text { Tectus pyramis } \\
\text { (Born, 1778) }\end{array}$ & - & 16 & 16 & 4 & 4 & 4 & - & - & - & 4 & 8 & 8 & - & - & - & 2 & 4 & 4 \\
\hline Turbinidae & & & & & & & & & & & & & & & & & & \\
\hline $\begin{array}{l}\text { Turbo petholatus } \\
\text { (Linnaeus, 1758) }\end{array}$ & - & 4 & 4 & - & - & - & 8 & 16 & 16 & 2 & 2 & 2 & - & - & 2 & - & - & - \\
\hline
\end{tabular}

Note: 'Hemagglutination activity was expressed as a titer, the reciprocal of the highest dilution showing positive hemagglutination. ${ }^{b}$ Native erythrocytes; ${ }^{c}$ Trypsin-treated erythrocytes; ${ }^{d}$ Papain-treated erythrocytes; ${ }^{e}$ Negative agglutination.

\section{Gastropods}

The extracts from 10 gastropod species surveyed agglutinated at least one type of erythrocytes tested (Table 1). The extract from Tectus conus agglutinated strongly with enzyme-treated rabbit and human A erythrocytes, but showed weak haemagglutination with sheep and human B, O erythrocytes. The extracts from Haliotis ovina and Lambis lambis agglutinated enzyme-treated animal erythrocytes, but showed no haemagglutination with human erythrocytes. The extract from Tutufa rubeta agglutinated strongly with enzyme-treated human A erythrocytes, but showed weak haemagglutination with the other types of erythrocytes, indicating that several gastropod species possessed human blood type specific lectins. The similar results had been reported from the survey for Philippine gastropod haemagglutination activity, which showed some agglutination activity against human red blood cell tested (Mojica et al., 2005). The results suggest that Vietnam marine invertebrates may be good sources of useful lectins for many biological applications.

\section{Sugar-binding specificities}

From the 4 active species, carbohydrate-binding specificity of each extract was examined for haemagglutination-inhibition test with a series of sugars and glycoproteins using ammonium sulfate precipitates prepared from each extract. The haemagglutination activities of two extracts from Tutufa rubeta and Pleuroploca trapezium were not inhibited by any of the monosaccharides and glycoproteins examined (Table 2). On the other hand, haemagglutination activities of extract from Tectus conus were inhibited by porcine stomach mucin and its asialo derivative bearing O-glycans, but no inhibited by other glycoproteins bearng high mannose, complex and hybrid type $\mathrm{N}$-glycans, such as fetuin, transferin and thyroglobulin, indicating that this invertebrate species contains, at least, a lectin specific for O-glycans. Interestingly, extract from Tridacna squamosa appears to recognize the non-reducing terminal $\mathrm{N}$-acetyl-D-galactosaminyl residue(s) of O-glycans, because its activity was strongly inhibited by porcine stomach mucin and its asialo derivative as well as by N-acetyl-Dgalactosamine, $\mathrm{D}$-galactose and $\mathrm{N}$-acetyl neuraminic acid. The porcine stomach mucin contains O-linked carbohydrate structures sharing the core 1 Gal $\beta 1-$ 3GalNAc disaccharide, which can be substituted by $\mathrm{N}$-acetyllactosamine branches terminated with fucose $(\alpha 1-2)-G a l$ (human blood group $H$ ), GalNAc $(\alpha 1-3)$ [Fuc $\alpha 1-2]$ Gal (human blood group A), or GlcNAc( $\alpha 1-4)-G a l$ at their non-reducing ends. Tn (GalNAc $(\alpha 1)$-Ser/Thr) and $\mathrm{T}$ (Gal $\beta(1-$ 3)GalNAc $\alpha 1$-Ser/Thr) antigens are also present in the porcine stomach mucin (Van Halbeek et al., 1982; Karlsson et al., 1997). In fact that elimination of sialic acid residues from porcine stomach mucin did not change inhibitory potential of parental glycoprotein, clearly indicating that the presence of $\mathrm{N}$-acetyl neuraminic acid (NeuAc) as a terminal residue of the carbohydrate did not affect the haemagglutination activity of $T$. squamosa. The data suggest that extract from $T$. squamosa recognized preferentially the terminal GalNAc/Gal units in porcine stomach mucin (Figure 2) and this invertebrate species contains, at least, a lectin specific for O-glycans.

Inhibition by mucins bearing $\mathrm{O}$-glycans that is related to GalNAc/Gal or GalNAc/NeuAc binding specificity reported for many lectins from marine invertebrates, such as tridacin from Tridacna Tridacna maxima (Baldo et al., 1978), PLC from Abalone Haliotis laevigata (Weiss et al., 2000), PPL from Oyster Pteria penguin (Naganuma et al., 
Journal of Biotechnology 15(4): 691-701, 2017

2006), BRL from Barnacle Balanus rostratus (Muramoto, Kamiya, 1986) and NnL from Jellyfish Nemopilema nomurai (Imamichi, Yokoyama, 2010).
All of them bound GalNAc/Gal substituted through $1-3,1-4$, or 1-2 linkages in O-linked mucin-type glycans.

Table 2. Hemagglutination-inhibition test of marine invertebrate extracts with sugars and glycoproteins.

\begin{tabular}{lllll}
\hline Sugars and glycoproteins & \multicolumn{3}{c}{ Samples } \\
\cline { 2 - 5 } & $\begin{array}{l}\text { Tridacna } \\
\text { squamosa }\end{array}$ & $\begin{array}{l}\text { Tectus } \\
\text { conus }\end{array}$ & Pleuroploca trapezium & $\begin{array}{c}\text { Tutufa } \\
\text { rubeta }\end{array}$ \\
\hline Sugars $(m M)$ & a & 25.0 & - & - \\
D-mannose & - & - & - & - \\
D-glucose & 6.25 & - & - & - \\
D-galactose & 12.5 & - & - & - \\
N-acetyl-D-mannosamine & 12.5 & - & - & - \\
N-acetyl-D-glucosamine & 3.12 & - & - & - \\
N-acetyl-D-galatosamine & 6.25 & - & - & - \\
N-acetyl neuraminic acid & & & & - \\
Glycoproteins $(\mu g / m L)$ & 7.81 & 125.0 & - & - \\
Porcine stomach mucin & 7.81 & 125.0 & - & - \\
Asialo-Porcine stomach mucin & - & - & - & - \\
Fetuin & - & - & - & - \\
Asialo-Fetuin & - & - & - & - \\
Transferin & - & - & - & - \\
Asialo-Transferin & - & - & - & - \\
Yeast Mannan & - & & - & - \\
Thyroglobulin & & - & - & - \\
\hline
\end{tabular}

Note: - ${ }^{a}$ Indicates no inhibition at $100 \mathrm{mM}$ for monosaccharides and at $2000 \mu \mathrm{g} / \mathrm{mL}$ for glycoproteins.

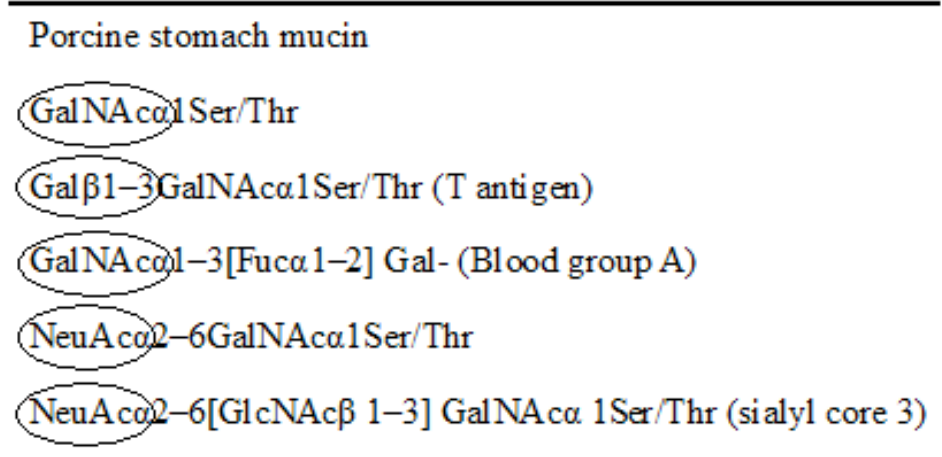

Figure 2. The putative epitopes recognized by haemagglutinin from $T$. squamosa in porcine stomach mucin are highlighted in oval. Gal: D-galactose; GalNAc: N-acetyl-D-galactosamine, NeuNAc: N-acetylneuraminic acid; GlcNAc: N-acetyl-Dglucosamine; Fuc: Fucose; Ser/Thr: Serine/Threonie. 
Effects of divalent cations, $\mathrm{pH}$, and temperature on haemagglutination activity

The effects of divalent cations, $\mathrm{pH}$, and temperature on haemagglutination activity of the extracts from some active species listed in table 2 were examined. The haemagglutination activities of extracts from $T$. rubeta and $P$. trapezium were unchanged after being dialyzed against $50 \mathrm{mM}$ EDTA and in the presence of $10 \mathrm{mM} \mathrm{CaCl} 2$ or $\mathrm{MgCl}_{2}$, indicating that haemagglutination activities of these extracts were not dependent on the presence of divalent cations. On the contrary, the haemagglutination activity of extracts from $T$. squamosa and T. conus were slightly decreased after being dialyzed by EDTA. Addition of $\mathrm{CaCl}_{2}$ or
$\mathrm{MgCl}_{2}$ at $10 \mathrm{mM}$ concentration restored almost the total haemagglutination activity initially.

As shown in Figure 3a, the haemagglutination activities of $T$. rubeta, $P$. trapezium, $T$. conus and $T$. squamosa extracts were unchanged even when heated at $50^{\circ} \mathrm{C}$ for $30 \mathrm{~min}$. However, their activities were significantly decreased as the incubation temperature exceeded $50^{\circ} \mathrm{C}$ and were completely lost by heating at $70^{\circ} \mathrm{C}$ for $30 \mathrm{~min}$. Most of the marine invertebrate extracts examined maintained their activities over a wide range of $\mathrm{pH}$ values between 3 and 8 with a slight decrease in activity in more alkaline media, except for activity of $T$. conus extract was unchanged at a $\mathrm{pH}$ range between 3 and 10 (Figure 3b).
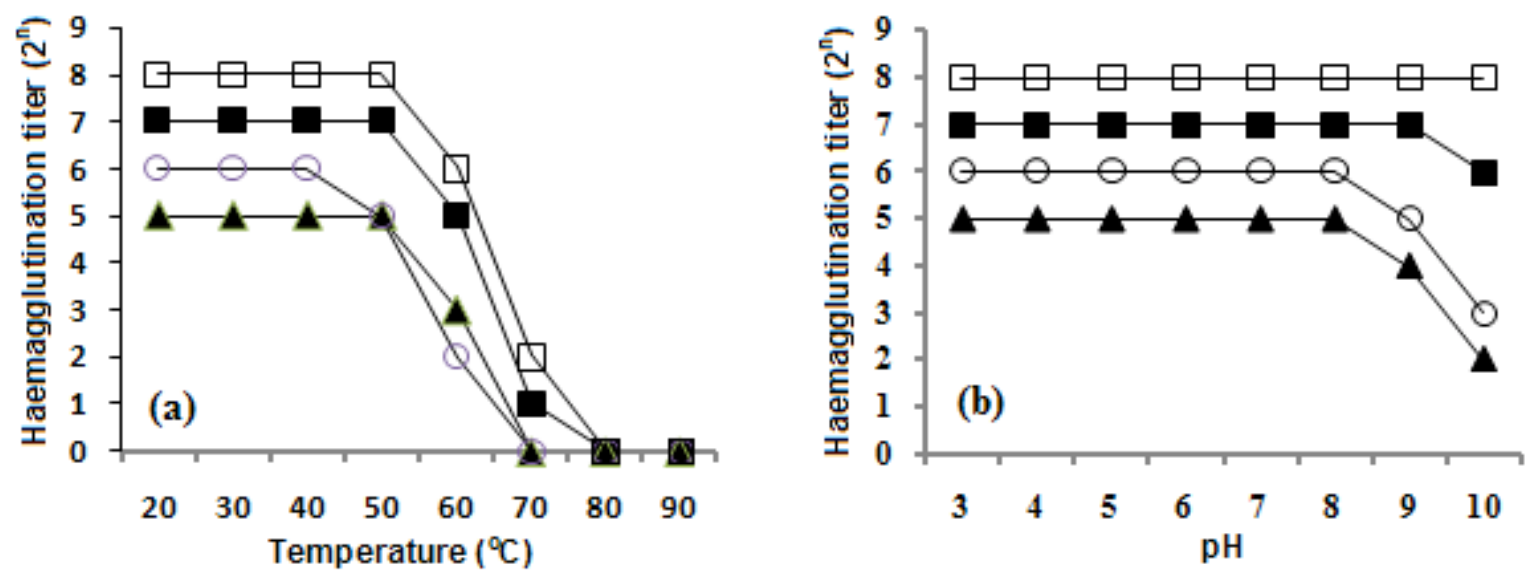

Figure 3. Effects of temperature (a) and pH (b) on haemagglutination activities of ammonium sulfate precipitates prepared from marine invertebrates. Pleuroploca trapezium $(-)$ ), Tutufa rubeta $(-\mathbf{\Lambda}-)$, Tridacna squamosa $(-\mathbf{-})$, Tectus conus $(\square)$. Values are means (there was no variance).

\section{CONCLUSION}

The 21 species of Vietnam marine invertebrates, including 11 bivalve and 10 gastropod species were examined for haemagglutination activity using native and enzyme-treated different animal and human erythrocytes. The 8 bivalve and 10 gastropod species were found to have haemagglutination activity toward at least one type of erythrocyte tested. A total of $86 \%$ of extracts from marine invertebrate species surveyed were active. The haemagglutinationinhibition tests indicated that extracts from Tridacna squamosa and Tectus conus might contain, at least, a lectin specific for O-glycans. On the other hand, the haemagglutination activities of four marine invertebrate extracts were stable over a wide range of $\mathrm{pH}$ and temperature. Thus, Vietnam marine invertebrates could be promising sources of useful lectins for applications. The wealth of information obtained in the present study would be helpful for identification of new lectins and for clarification of the biological significance. Isolation and characterization studies on lectins from these marine invertebrates are currently underway.

Acknowledgements: This research was supported by Vietnam Academy of Science and Technology (VAST) under grant number VAST06.04/16-17. The 
authors wish to thank MSc. Bui Quang Nghi Institute of Oceanography, Vietnam for the identification of marine invertebrate samples.

\section{REFERENCES}

Austin B (1988) Marine Microbiology. Cambridge. Press, Karachi, Pakistan. University Press, Cambridge.

Arreguin-Espinosa R, Fenton B, Vazquez-Contreras E, Arreguin B, Garcia Hernandez E (2001) PFA, a novel mollusk agglutinin, is structurally related to the ribosomeinactivating protein superfamily. Arch Biochem Biophys 394: $151-155$.

Baldo BA, Sawyer WH, Stick RV, Uhlenbruck G (1978) Purification and characterization of a galactan-reactive agglutinin from the clam Tridacna maxima (Roding) and a study of its combining site. Biochem J 175: 467-477.

Bayne CJ (1990) Phagocytosis and non-self recognition in invertebrates. BioScience 40: 723-731.

Canesi L, Gallo G, Gavioli M, Pruzzo C (2002) Bacteriahemocyte interactions and phagocytosis in marine bivalves. Microsc Res Tech 57: 469-476.

Cao Đăng Nguyên (1998) Điều tra lectin từ các mẫu sinh vật thường gặp ở vùng biển Hải Hậu. Tạp chí Sinh hoc 20: 122-127.

Cao Đăng Nguyên, Nguyễn Quốc Khang (1998) Tinh sạch, hoạt tính sinh học và khả năng phản ứng tế bào của lectin trai tai tượng (Tridacna elongata). Tạp chí Di truyền hoc và Úng dụng 2: 32-35.

Cao Đăng Nguyên, Nguyễn Quốc Khang, Trần Thị Lệ Hằng (2000) Đặc trưng lectin hai loài cá Chình Hoa và cá Chình Nhật (Anguilla bengalesnis, Anguila mamorata) ở vùng biển Thừa Thiên Huế. Tap chí Sinh họ 9: 153-158.

Cao Đăng Nguyên, Đặng Thị Thảo, Nguyễn Bá Hai (2008) Điều tra, tinh sạch và tính chất đặc trưng của lectin trong một vài loài thuộc lớp chân bụng sống ở nước ngọt Thừa Thiên Huế. Tạp chi Công nghệ sinh học 6: 867-872.

Chu FLE (1988) Humoral defense factor in marine bivalves. Am Fish Soc Spec Publ 18: 178-188.

Cooper EL, Rinkevich B, Uhlenbruck G, Valembois P (1992) Invertebrate immunity: Another viewpoint. Scand $J$ Immunol 35: 247-266.

Gabius HJ (1997) Animal lectins. European Journal of Biochemistry 243: 543-576.

Imamichi Y, Yokoyama Y (2010) Purification, characterization and cDNA cloning of a novel lectin from the jellyfish Nemopilema nomurai. Comp Biochem Physiol B Biochem Mol Biol 156: 12-18.

Kawabata S, Tsuda R (2002) Molecular basis of non-self recognition by the horseshoe crab tachylectins. Biochim Biophys Acta 1572: 414-421.
Kawsar SMA, Takeuchi T, Kasai KI, Fuji Y, Matsumoto R, Yasumitsu H, Ozeki Y (2009) Glycan-binding profile of a D-galactose binding lectin purified from the annelid, Perinereis nuntia ver vallata. Comp Biochem Physiol 152B: 382-389.

Karlsson NG, Nordman H, Karlsson H, Carlstedt I, Hansson GC (1997) Glycosylation differences between pig gastric mucin populations: A comparative study of the neutral oligosaccharides using mass spectrometry. $J$ Biochem 326: 911-917.

Lakhtin V, Lakhtin M, Alyoshkin V (2011) Lectins of living organisms. The overview. Anaerobe 17: 452-455.

Le Dinh Hung, Hori K, Huynh Quang Nang (2009a) Screening and preliminary characterization of hemagglutinins in Vietnamese marine algae. $J$ Appl Phycol 21: 89-97.

Le Dinh Hung, Sato T, Shibata H, Hori K (2009b) Biochemical comparison of lectins among three different color strains of the red alga Kappaphycus alvarezii. Fish Sci 75: 723730 .

Le Dinh Hung LD, Sato Y, Hori K (2011) High-mannose $\mathrm{N}$-glycan specific lectins from the red alga Kappaphycus striatum (Carrageenophyte). Phytochemistry 72: 855-861.

Le Dinh Hung, Bui Minh Ly, Vo Thi Dieu Trang, Ngo Thi Duy Ngoc, Le Thi Hoa, Phan Thi Hoai Trinh (2012) A new screening for hemagglutinins from Vietnamese marine macroalgae. J Appl Phycol 24: 227-235.

Le Dinh Hung, Hirayama M, Bui Minh Ly, Hori K (2015a) Purification, primary structure and biological activity of high-mannose $N$-glycan specific lectin from the cultivated Eucheuma denticulatum. J Appl Phycol 27: 1657-1669.

Le Dinh Hung, Hirayama M, Bui Minh Ly, Hori K (2015b) Biological activity, cDNA cloning and primary structure of lectin KSA-2 from the cultivated red alga Kappaphycus striatum (Schmitz) Doty ex Silva. Phytochemistry Letters 14: 99-105.

Luk'yanov PA, Chernikov OV, Kobelev SS, Chikalovets IV, Molchanova VI, Li W (2007) Carbohydrate-binding proteins of marine invertebrates. Russ J Bioorg Chem 33: 161-169.

Mojica ERE, Deocaris CC, Merca FE (2005) A survey of lectin-like activity in Philippine marine invertebrates. Philipp J Sci 134: 135-142.

Molchanova V, Chikalovets I, Chernikov O, Belogortseva N, Wang JH, Yang DYO, Zheng YT, Lukyanov P (2007) A new lectin from the sea worm Serpula vermiculasis: Isolation, characteriza sition, and anti-HIV activity. Comp Biochem Physiol 145C: 184-193.

Moura RM, Queiroz AFS, Fook JMSLL, Dias ASF, Monteiro NKV, Ribeiro JKC, Moura GEDD, Macedo LLP, Santos EA, Sales MP (2006) CvL, a lectin from the marine sponge Cliona varians: Isolation, characterization and its effects on pathogenic bacteria and Leishmania 
promastigotes. Comp Biochem Physiol Mol Integr Physiol 145: 517-523.

Moura RM, Melo AA, Carneiro RF, Rodrigues CR, Delatorre P, Nascimento KS, Saker-Sampaio S, Nagano CS, Cavada BS, Sampaio AH (2015) Hemagglutinating/Hemolytic activities in extracts of marine invertebrates from the Brazilian coast and isolation of two lectins from the marine sponge Cliona varians and the sea cucumber Holothuria grisea. An Acad Bras Cienc 87: 973-984.

Muramoto K, Kamiya H (1986) The amino-acid sequence of a lectin of the acorn barnacle Megabalanus rosa. Biochimica et Biophysica Acta 874: 285-295.

Naganuma T, Ogawa T, Hirabayashi J, Kasai K, Kamiya H, Muramoto K (2006) Isolation, characterization and molecular evolution of a novel pearl shell lectin from a marine bivalve, Pteria penguin. Molecular Diversity 10: 607-618.

Nesser R, Koellreautter B, Wuersch P (1986) Oligomanoside type glycopeptides inhibiting adhesion of Escherichia coli strains mediated by type 1 pili, preparation of potent inhibitors from plant glycopeptides. Infect Immun 58: 428-436.

Nguyễn Quốc Khang, Trần Quốc Vượng, Cao Đăng Nguyên (2000) Một vài tính chất lý, hoá học của lectin cá nheo (Prasilurus asotus). Tap chi Sinh hoc 22: 149-152.

Renwrantz L (1986) Lectins in molluscs and arthropods: their occurrence, origin and roles in immunity. Symp Zool
Soc Lond 56: 81-93.

Van Halbeek H, Dorland L, Vliegenthart JFG, Kochetkov K, Arbatsky NP, Derevitskaya VA (1982) Characterization of the primary structure and the microheterogeneity of the carbohydrate chains of porcine blood-group $\mathrm{H}$ substance by $500-\mathrm{MHz} 1 \mathrm{H}-\mathrm{NMR}$ spectroscopy. Eur J Biochem 127: 21-29.

Vasta GR (1992) Invertebrate lectins: distribution, synthesis, molecular biology and function. In: Allen HJ and Kisalius EC. (eds.), Glycoconjugates, composition, structure and function. Marcel Dekker, New York.

Vo TS, Kim SK (2010) Potential anti-HIV agents from marine resources: An overview. Marine Drugs 8: 28712892.

Wang JH, Kong J, Li W, Molchanova V, Chikalovets I, Belogortseva N, Luk'yanov P, Zheng YT (2006) A $\beta$ galactose-specific lectin isolated from the marine worm Chaetopterus variopedatus possesses anti-HIV-1 activity. Comp Biochem Physiol 142C: 111-117.

Weiss IM, Kaufmann S, Mann K, Fritz M (2000) Purification and characterization of perlucin and perlustrin, two new proteins from the shell of the mollusc Haliotis laevigata. Biochemical and Biophysical Research Communications 267: 17-21.

Xiong CN, Li W, Liu H, Zhang W, Dou JL, Bai XF, Du YG, Ma XJ (2006) A normal mucin-binding lectin from the sponge Craniella australiensis. Comp Biochem Physiol C Toxicol Pharmacol 143: 9-16.

\title{
HOẠT TÍNH NGƯNG KẾT HỔNG CẦU CỦA CÁC DỊCH CHIẾT TỪ MộT SỐ LOÀI ĐộnG VẠTT KHÔNG XƯƠNG SỐNG BIỂN VIỆT NAM
}

\author{
Đinh Thành Trung ${ }^{1}$, Võ Thị Diệu Trang ${ }^{1}$, Ngô Thị Duy Ngọcc ${ }^{1}$ Phan Thị Hoài Trinh ${ }^{1}$, Trần Thị Hải \\ Yến ${ }^{2}$, Lê Đình Hùng ${ }^{1}$ \\ ${ }^{1}$ Viện Nghiên cứu và Ứng dụng Công nghệ Nha Trang, Viện Hàn lâm Khoa học và Công nghệ Việt Nam \\ ${ }^{2}$ Truò̀ng Trung học phổ thông chuyên Lê Quý Đôn, Khánh Hòa
}

\section{TÓM TẮT}

Dịch chiết từ 21 loài động vật không xương sống biển Việt Nam, bao gồm 11 loài động vật hai mảnh vỏ và 10 loài chân bụng, đã được kiểm tra hoạt tính ngưng kết máu với các dạng hồng cầu khác nhau của động vật và người ở dạng tự nhiên và dạng đã xử lý enzyme. 8 loài động vật hai mảnh vỏ và 10 loài chân bụng thể hiện hoạt tính ngưng kết với ít nhất một trong số các hồng cầu thử nghiệm. Tổng số $86 \%$ dịch chiết từ loài động vật không xương sống biển được dùng để khảo sát đã có hoạt tính ngưng kết với ít nhất một dạng hồng cầu. Dịch chiết từ 2 loài động vật hai mảnh vỏ (Tridacna squamosa và Geloina coaxans) và 3 loài chân bụng (Tutufa rubeta, Pleuroploca trapezium và Tectus conus) đã có hoạt tính ngưng kết mạnh với các dạng hồng cầu nhóm máu người $\mathrm{A}, \mathrm{B}, \mathrm{O}$, thỏ và ngựa đã được xử lý enzyme. Trong thí nghiệm ức chế sự ngưng kết máu với các đường và các glycoprotein khác nhau, hoạt tính ngưng kết hồng cầu của hai dịch chiết từ $T$. rubeta và $P$. trapezium không bị ức chế bởi các đường đơn và các glycoprotein, trong khi đó hoạt tính của hai dịch chiết từ $T$. squamosa và $T$. conus bị ức chế mạnh bởi porcine stomach mucin, chỉ ra sự có mặt của lectin đặc hiệu cho $\mathrm{O}$-glycan của các loài này. Hoạt tính ngưng kết hồng cầu của các dịch chiết từ $T$. rubeta và $P$. trapezium bền trong phạm vi rộng của nhiệt độ và $\mathrm{pH}$, và không phụ thuộc vào sự có mặt của cation hóa trị hai, trái lại hoạt tính ngưng kết hồng cầu của hai dịch chiết từ $T$. squamosa và $T$. conus phụ thuộc nhẹ vào sự có mặt của cation 
Journal of Biotechnology 15(4): 691-701, 2017

hóa trị hai. Kết quả gợi ý rằng động vật không xương sống biển Việt nam có thể là một nguồn lectin giá trị cho sử dụng trong hóa sinh và y sinh.

Từ khóa: Đặc tính liên kết carbohydrate; Độ bền; Động vật không xưong sống biển; Hoạt tính ngung kết hồng cầu; Khảo sát; Lectin 